\title{
Tracing Eugene Goossens: Goossensiana in the National Library of Australia
}

\section{Stephen Mould}

My heart just loosens

When I'm listening to Mr Goossens

'Russian Blues,' Noël Coward (1921)

The National Library of Australia (NLA) website describes the 'Eugene Goossens Collection' (EGC) as 'a collection of scores of approximately 220 volumes, dating from the 1720s to 1970s, most of which were owned and used by Goossens. ${ }^{1}$ It also states that'some of the music ... was obviously owned by Eugene Goossens, notated with 'EG' and a running number, and had been incorporated into a larger batch of material formerly owned by Symphony Australia. ${ }^{2}$ At the time of writing, the NLA website identifies this material as 'The Eugene Goossens Collection of Musical Scores,' an attribution that requires further examination.

\section{Sir Eugene Goossens III}

Eugene Aynsley Goossens (1893-1962) was a notable English conductor and composer of Belgian origins, the third generation of 'Eugenes' in his family, all of whom were conductors. ${ }^{3}$

\footnotetext{
1 'Symphony Australia Collection,' National Library of Australia, https:/ /www.nla.gov.au/collections / guide-selected-collections/symphony-australia-collection.

${ }^{2}$ Lisa Mackie, 'Cataloguing the Eugene Goossens Collection of Music Scores,' National Library of Australia, 17 Jan. 2011, https: / /www.nla.gov.au/stories/blog/behind-the-scenes/2011/01/17/ cataloguing-theeugene-goossens-collection-of-music-scores. The catalogue of the collection currently lists 183 items.

${ }^{3}$ He was preceded by Eugène Goossens I (1845-1906) and Eugène Goossens II (1867-1958).
} 
Figure 1. Eugene Goossens, ca 1920. Postcard produced by his publisher, Chester Music, London (private collection, Sydney)

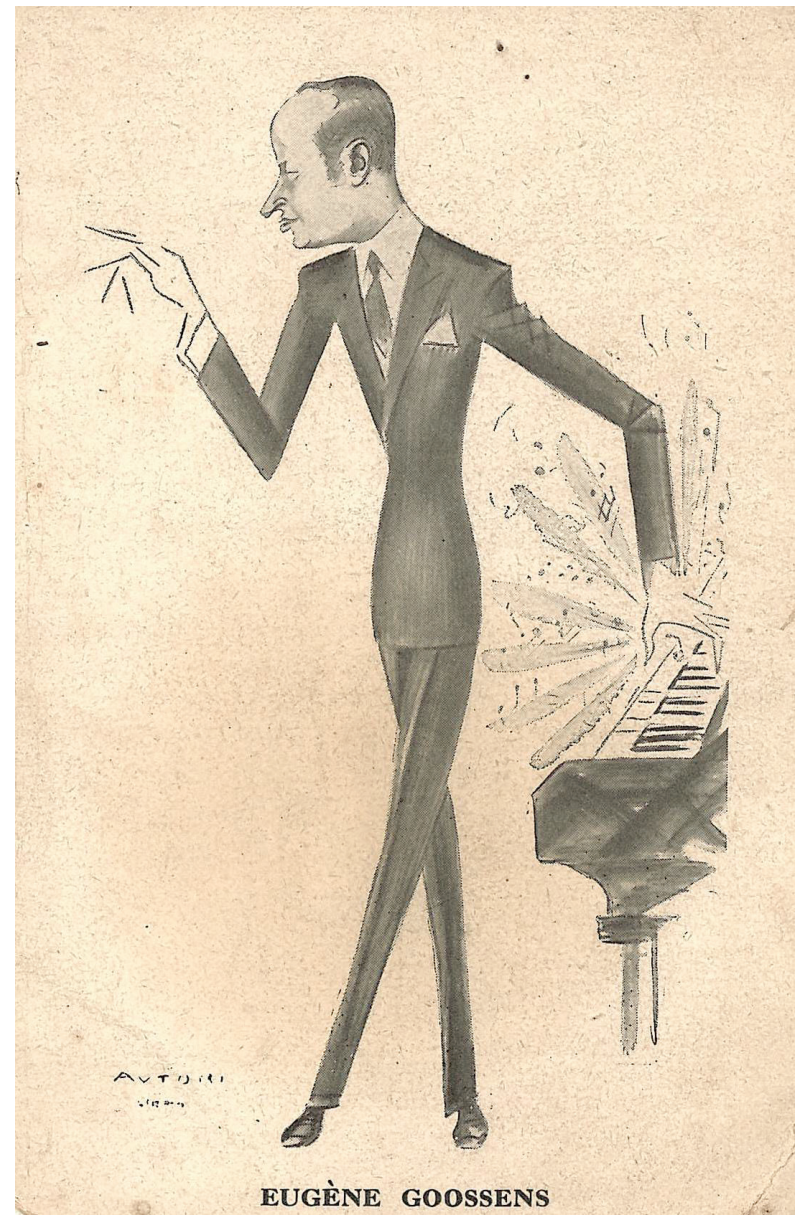

He was influenced and assisted in his early career by Sir Thomas Beecham, whose flamboyant manner the younger man emulated, particularly in the financing of large-scale orchestral concerts designed to enhance his reputation, where he showcased works by avant-garde composers such as Arnold Schoenberg and Igor Stravinsky. Goossens' fiscal position was not as solid as Beecham's, and having depleted his resources he turned his attentions to the United States of America, where he held important posts as conductor of the Rochester Philharmonic Orchestra (1923-1931) and the Cincinnati Symphony Orchestra (1931-1946). During these years Goossens toured widely, guest-conducting in Europe, the United Kingdom, and throughout the USA. In 1947, following engagements in Australia, Goossens was appointed Chief Conductor of the Sydney Symphony Orchestra (SSO), which was in need of a leading musical force to galvanise it, expand its repertoire, and develop its stylistic range. Goossens accepted the opportunity in Sydney as a challenge that he could not refuse, and became concurrently conductor of the SSO and Director of the New South Wales State Conservatorium of Music (SCM). He was effectively the most influential musical identity in Australia, earning a salary that exceeded that of the then prime minister. His prodigious activity was bound to alienate 
some of the local musical establishment, who perceived the conductor's personal manner to be somewhat high-handed, and he made enemies in rehearsal as well as behind the scenes. Without doubt, his tenure with the SSO was a musical and artistic triumph, which transformed the orchestra and established a new level of music-making. Goossens broadened the SSO's repertoire, particularly in the area of contemporary music, and he led the Australian premieres of dozens of works. The programs he created reveal an extraordinary diversity of repertoire, presented in seasons that were designed and led by a polyglot who was at ease across effectively all musical styles and epochs.

While the public was acquainted with Goossens' patrician and genteel manner, there was another, less public side to him. On 9 March 1956, the recently knighted Goossens flew into Sydney, returning from a European conducting tour. Normally, the high-profile conductor would walk straight through customs to be met by a chauffeur. On this occasion, Goossens was detained, and his bags-which he stated contained music scores-were searched, revealing over one thousand items of a pornographic nature. It is likely that these items (which have disappeared without trace) would be regarded with little more than mild amusement today, but in Sydney in the 1950s, the incident caused a scandal that rocked not only the music community, but also the social fabric of the city. The matter was heard in court- the conductor did not appearand Goossens received the maximum fine of $£ 100$ on charges of importing prohibited goods to Australia. More serious charges were never laid, and the implication is that in resigning his posts and agreeing to leave the country, Goossens had spared himself more serious and potentially more humiliating consequences. ${ }^{4}$ It emerged that Goossens had been intimately involved with a notorious artist and occultist, Rosaleen Norton, known as the 'Witch of Kings Cross.' The materials that Goossens attempted to bring into Australia were destined for Norton and her circle, for use in their occult rituals, in which Goossens was an enthusiastic participant.

Goossens had been under investigation for some time and the police at the airport were tipped off; however, the conductor maintained that he was a victim who had, in effect, been 'set up'. Over the years there have been numerous theories about professional jealousies within the music fraternity, of musicians who wanted to bring down a figure who many felt simply had too much power and influence over the local industry. What is certain is that Goossens' reputation and career was ruined within a matter of hours of returning to Australia; his wife left him, and he was forced to resign from both his professional posts. Goossens was allowed to retain his knighthood, but was financially ruined. He departed hurriedly and anonymously for the UK, where he lived out the rest of his life in relative obscurity. Despite remaining active as a guest conductor and making a number of recordings, he failed to secure a significant post with an orchestra or an opera house. The Australian scandal was undoubtedly a factor in the demise of his career, but it is also likely that the conductor had simply been away from the British musical scene for too long, and the industry had outgrown him. Goossens, the musical visionary who articulated the concept and chose the site of the Sydney Opera House, never returned to Australia. ${ }^{5}$

\footnotetext{
${ }^{4}$ Michelle Arrow, 'Sir Eugene Goossens: Sex, Magic and the Maestro,' Rewind (Sydney: Australia, Australian Broadcasting Corporation), 2004.

${ }^{5}$ See Donald Westlake, Eugene Goossens: Bohemian in Exile-A Life in the Voices of his Time (unpublished manuscript in author's possesion); and Carole Rosen, The Goossens: A Musical Century (London: André Deutsch, 1993).
} 


\section{The ‘Goossens Collection' (GC)}

In recent years the study of the marked scores of conductors has emerged as a valuable field of enquiry. Most conductors maintain a personal library of scores of their active repertoire, which they may mark in a variety of ways. Scores may be annotated with lists of performance dates; private musings about the significance of a work; structural analyses; Retuschen; ${ }^{6}$ bowings, phrasing, and other details that relate to performance practice. While such scores are generally studied in relation to the specific markings of the conductor who created them, other aspects of the scores and their provenance may suggest different approaches. While researching the scope and contents of the EGC, I decided to investigate the collection from an ethnographical perspective: to consider it in terms of the insights that it may reveal into its owner's life and career. The process examined the EGC with the intention of identifying scores with sound Goossens provenance, possible Goossens provenance, or those bearing no discernible relation to the conductor. The GC - the eighty scores within the EGC with sound Goossens provenance-is of significant value to Goossens scholarship, having been acquired from the conductor at a particularly tragic and defining point in his life. It presents a snapshot through which information about his career and musical tastes can be gleaned.

The GC was acquired by the Australian Broadcasting Commission (ABC) in 1956 as the conductor hurriedly departed Australia. The ABC purchased a 'substantial music collection' belonging to Goossens, for the sum of $£ 42010$ s. ${ }^{7}$ It is unlikely that Goossens would have disposed of his entire music library at that time, as the scores of his staple conducting repertoire were a fundamental career resource. ${ }^{8}$ The purchase price of the GC is difficult to quantify today; in raw figures, it equates to approximately AU $\$ 7000$ in $2021 .{ }^{9}$ With around eighty scores, this would average out at around $\$ 90$ per score, which could well represent the purchase price for many of the items. Many scores are inscribed by their composers, and a few have detailed markings from Goossens, but in the climate of 1956, although such annotations may have been considered of intrinsic interest, they would not necessarily have added monetary value. What constitutes significance and adds market value to second-hand music scores has changed considerably over the ensuing decades, and no valuation or inventory survives from 1956 (although the precise number of the sum paid suggests that some valuation method was applied). As Goossens was selling off his house and most of his personal property at the time of the acquisition, it is possible that he offered these scores to the $\mathrm{ABC}$, and that a senior figure (perhaps Charles Moses) offered a generous sum in order to, in some way, mitigate the unfortunate circumstances Goossens faced at the time. The exact details of the purchase remain

\footnotetext{
${ }^{6}$ Retuschen is the practice of retouching, or 'touching up' a composer's score, comparable with retouching a photograph. This was a standard practice in late nineteenth- and early twentieth-century central Europe by which a conductor would make (generally) small adjustments to a past composer's score to render them performable for modern orchestras and performance venues.

${ }^{7}$ David Salter, 'The Conductor, the Witch and the Vice Squad,' Sydney Morning Herald, 'The Good Weekend', 1 July 1999, 21.

${ }^{8}$ A number of boxes of scores were sent to London following Goossens' departure from Sydney by Phyllis Williams, his secretary at the SCM. These boxes presumably contained his core conducting repertoire, which is confirmed by correspondence from Goossens to Williams dated 29 August 1956 about a 'box of music' that had not yet arrived in London, containing the score of an arrangement of Schumann's Carnaval, which he was soon to conduct in the Albert Hall. See Westlake, Eugene Goossens, 336-38.

9 'Value of 1956 Australian Dollars today,' Inflationtool, https://www.inflationtool.com/australiandollar/1956-to-present-value.
} 
unknown, and the GC itself does not reveal a clear motive, either for the sale or the purchase, although it seems likely that the bulk of the material sold was not Goossens' core conducting repertoire; he may simply have been divesting himself of works that he felt would not be part of his repertoire in the future.

To determine which items within the EGC were originally purchased from Goossens in 1956 (in other words, which scores constituted the GC), approximately 183 scores in the EGC were examined. The NLA website notes that 'only a certain number of the titles in this Collection belonged to, or were collected by, Goossens himself. These are identified by the existing Symphony Australia labels with the prefix "EG"'; as well as that, 'many of the titles post-date Goossens' life.'10 Items published after 1956 could not have formed part of Goossens' library, and are easily identified. ${ }^{11}$ Most, but not all the items owned by Goossens have attached catalogue labels. These labelled items would have been catalogued sometime after 1956, and held in the ABC Federal Music Library in Sydney (see Table 1). There are also a number of unlabelled items that are undoubtedly from Goossens' library, provenance being established by inscriptions (see Table 2). There remain a number of questionable items that may have belonged to Goossens, a sampling of which will be described and considered (see Table 3). Finally, there are items that can be discounted from any association with Goossens, due to other marks of ownership, notably those of William Saurin Lyster and Fred Haines, linking them with an earlier period in Australian history that predates Goossens' residence in Australia. It therefore emerges that the EGC encompasses an amalgam of collections from a number of sources, as are set out in the tables below.

Table 1. The Goossens Collection, Nos. 1-69 12

\begin{tabular}{|l|l|l|l|l|}
\hline $\begin{array}{l}\text { EG } \\
\text { Identifier }\end{array}$ & Composer & Work & Publisher & $\begin{array}{l}\text { NLA Bib } \\
\text { ID }\end{array}$ \\
\hline EG1 & Schuman, [W.] & American Festival Overture & Schirmer & 4981095 \\
\hline EG2 & Bax, A. & The Tale the Pine-trees Knew & Murdoch & 4981012 \\
\hline EG3 & Becker, J. & $\begin{array}{l}\text { Concerto arabesque for Piano and } \\
\text { Orchestra }\end{array}$ & New Music & 4977207 \\
\hline EG4 & Becker, J. & Concerto for Horn in F & New Music & 4976909 \\
\hline EG5 & Becker, J. & $\begin{array}{l}\text { Soundpiece No. 2, Homage to } \\
\text { Haydn }\end{array}$ & New Music & 4976893 \\
\hline EG6 & Boelza, I. & Simfonĩia No. 1, op. 8 & $\begin{array}{l}\text { State Music } \\
\text { Publishing House }\end{array}$ & 4976837 \\
\hline EG7 & Gusikoff & O, Susanna: Variations & Levant & 4976885 \\
\hline EG8 & Arcadelt, J. & $\begin{array}{l}\text { The Chansons of Jacques } \\
\text { Arcadelt, vol. 1: Le Roi et Ballard }\end{array}$ & Smith \& Co & 4977711 \\
\hline
\end{tabular}

10 'Eugene Goossens collection of music scores [music],' National Library of Australia (catalogue entry), https: / / catalogue.nla.gov.au/Record/4970820.

${ }^{11}$ The EGC includes scores by Olivier Messiaen (published c. 1972) and Peter Sculthorpe (published c. 1964).

${ }^{12}$ To access these items on the NLA website, either the 'EG' identifier (LH column) or the Bib ID number (RH column) can be entered into the 'FIND' function at https: / / nla.gov.au/nla.cat-vn4970820. NLA Bib ID numbers appear in the main text within square brackets. 


\begin{tabular}{|c|c|c|c|c|}
\hline EG9 & $\begin{array}{l}\text { Bach, J.S. } \\
\text { [transc. Kramer] }\end{array}$ & $\begin{array}{l}\text { 'O man, lament thy grievous } \\
\text { sin': Choral Prelude Transcribed } \\
\text { for String Orchestra }\end{array}$ & Witmark & 4981256 \\
\hline EG10 & Baldwin, S. & Symphonic Rhapsody No. 4 & Fischer & 4982924 \\
\hline EG11 & Dubensky, A. & Gossips [two copies] & Fischer & 4979923 \\
\hline EG12 & Esplá, O. & El sueño de Eros: poema sinfónico & U.M.E. & 4979910 \\
\hline EG13 & Esplá, O. & Antaño & U.M.E. & 4979906 \\
\hline EG14 & Finn, W.J. & $\begin{array}{l}\text { Orchestral Settings of Five A } \\
\text { Cappella Numbers of the 16th } \\
\text { Century }\end{array}$ & PC of MS & 4979842 \\
\hline EG15 & Foerster, A.M. & $\begin{array}{l}\text { Verzweiflung: Call to Charon, aria } \\
\text { op. } 51\end{array}$ & Fischer & 4979811 \\
\hline EG16 & Gaul, H. & Three Palestinian Pastels & Fischer & 4980481 \\
\hline EG17 & [Gershwin] & [Lullaby for String Quartet] & [New World] & LOST \\
\hline EG18 & De Lamarter, E. & $\begin{array}{l}\text { The Black Orchid-Concert Suite } \\
\text { drawn from Music for a Highly } \\
\text { Stylized Ballet-Satire }\end{array}$ & Edward Bros. & 4980451 \\
\hline EG19 & Kaun, B. & $\begin{array}{l}\text { Sinfonia Concertante for Horn } \\
\text { and Orchestra }\end{array}$ & Jupiter & 4980408 \\
\hline EG20 & Maganini & $\begin{array}{l}\text { Genevieve: A Romantic } \\
\text { Rhapsody in Variation Form for } \\
\text { Symphony Orchestra }\end{array}$ & Carl Fischer & 4980355 \\
\hline EG21 & $\begin{array}{l}\text { Mozart } \\
\text { [transc. Eric } \\
\text { Werner] }\end{array}$ & $\begin{array}{l}\text { Fantasy for a Musical Clock, KV } \\
\text { 608. Transcribed for Orchestra } \\
\text { from the Original 4-Line Score }\end{array}$ & AMP & 4983529 \\
\hline EG22 i/ii & Holbrooke & $\begin{array}{l}\text { Les Hommages: Symphony No. } 1 \\
\text { for Grand Orchestra, op. } 40\end{array}$ & $\begin{array}{l}\text { Modern Music } \\
\text { Library }\end{array}$ & $\begin{array}{l}4983464 \\
4983441\end{array}$ \\
\hline EG23 & Beethoven & $\begin{array}{l}\text { Symphony No. } 2 \text { in D Major, } \\
\text { op. } 36\end{array}$ & Schott & 4983512 \\
\hline EG24 & Beethoven & $\begin{array}{l}\text { Symphonies No. } 5 \text {, op. } 67 \text { in } \\
\text { C minor and No. } 6 \text {, op. } 68 \text { in F } \\
\text { major }\end{array}$ & Peters & $\begin{array}{l}4983574 \\
4983575\end{array}$ \\
\hline EG25 & Gluck & $\begin{array}{l}\text { Iphigenia in Aulis: Oper in } 3 \\
\text { Akten }\end{array}$ & Peters & 4983496 \\
\hline EG26 & Brahms & Triumphlied, op. 55 & Simrock & 4982905 \\
\hline EG27 & Cole, U. & $\begin{array}{l}\text { Divertimento for String } \\
\text { Orchestra and Piano }\end{array}$ & Fisher & 5009410 \\
\hline EG28 & Carbonara, G. & $\begin{array}{l}\text { Ode to Nature - Symphonic } \\
\text { Impressions (For Orchestra) }\end{array}$ & M.S. & 5009342 \\
\hline EG29 & Brusselmans & Rhapsodie flamande & Cranz & 5009328 \\
\hline EG30 & David, F. & $\begin{array}{l}\text { Le désert-ode symphonie en trois } \\
\text { parties }\end{array}$ & Schott & 5009984 \\
\hline EG31 & Haydn & Ouverture: für Orchester & Rieter - Biedermann & 4983226 \\
\hline EG32 & Holbrooke & $\begin{array}{l}\text { Bronwen: A Music Drama (no. } \\
\text { 3), op. } 75\end{array}$ & Chester & 4982974 \\
\hline
\end{tabular}




\begin{tabular}{|c|c|c|c|c|}
\hline EG33 & Haussermann & $\begin{array}{l}\text { Concerto for Voice and } \\
\text { Orchestra, op. } 25\end{array}$ & Boosey & 5009305 \\
\hline EG34 & Steinert & Leggenda sinfonica & Universal & 4983371 \\
\hline EG35 & Spialek, H. & Sinfonietta & Chappell & 4983229 \\
\hline EG36 & Saminsky, L. & $\begin{array}{l}\text { Stilled Pageant = Fêtes passes: } \\
\text { op. } 48\end{array}$ & Senart & 4983393 \\
\hline EG37 & Pahissa, J. & $\begin{array}{l}\text { Sinfonia ( } 2 a \text {.) para gran orquesta } \\
\text { de cuerda }\end{array}$ & UME & 4981076 \\
\hline EG38 & Migot, G. & $\begin{array}{l}\text { Hagoromo: symphonie } \\
\text { choréographique et lyrique }\end{array}$ & Senart & 4983217 \\
\hline EG39 & Kalniņš A. & $\begin{array}{l}\text { Banjuta: opera } 4 \text { cēlienos = Oper } \\
\text { in } 4 \text { Akten }\end{array}$ & PBC & 4983174 \\
\hline EG40 & Jacobi & Indian Dances & Universal & 4981986 \\
\hline EG41 & Jacobi & $\begin{array}{l}\text { Concerto for Violoncello and } \\
\text { Orchestra }\end{array}$ & Universal & 4981979 \\
\hline EG42 & Stravinsky & $\begin{array}{l}\text { Suite de l'oiseau de feu: for } \\
\text { Orchestra }\end{array}$ & Chester & 4983480 \\
\hline EG43 & Walton & $\begin{array}{l}\text { Concerto for Violin and } \\
\text { Orchestra }\end{array}$ & OUP & 4982149 \\
\hline EG44 & Shostakovich & $\begin{array}{l}\text { Seventh Symphony for } \\
\text { Orchestra, op. } 60 \text { ( } 3 \text { copies) }\end{array}$ & SMP Moscow & 4980014 \\
\hline EG45 & Elgar & $\begin{array}{l}\text { Introduction and Allegro for } \\
\text { Strings (Quartet and Orchestra), } \\
\text { op. } 47\end{array}$ & Novello & 4982811 \\
\hline EG46 & Schoenberg & $\begin{array}{l}\text { Fünf Orchesterstücke, } \\
\text { op. } 16\end{array}$ & Peters & 4982646 \\
\hline EG47 & Bax, A. & Fifth Symphony for Orchestra & Murdoch & 4982940 \\
\hline EG48 & $\begin{array}{l}\text { Hanson } \\
\text { [Howard] }\end{array}$ & Symphony No. 3 & Birchard & 5009953 \\
\hline EG49 & Holst & $\begin{array}{l}\text { Double Concerto: for Two } \\
\text { Violins and Orchestra, op. } 49 \\
\text { [orch. score \& piano reduction] }\end{array}$ & Curwen & $\begin{array}{l}5009510 \\
5009513\end{array}$ \\
\hline EG50 & Copland & Two Pieces for String Orchestra & Arrow & 5009893 \\
\hline EG51 & Creston & $\begin{array}{l}\text { Partita for Flute and Violin or } 2 \\
\text { Violins with String Orchestra }\end{array}$ & Sprague-Coleman & 5009949 \\
\hline EG52 & Bantock & $\begin{array}{l}\text { Pagan Symphony: 'Et ego in } \\
\text { Arcadia vixi' }\end{array}$ & Williams & 5010074 \\
\hline EG53 & Bliss & A Colour Symphony & $\mathrm{BH}$ & 5009465 \\
\hline EG54 & Wagner, Joseph & $\begin{array}{l}\text { Rhapsody (Two Themes with } \\
\text { Variations): For Clarinet Solo, } \\
\text { Piano and String Orchestra }\end{array}$ & BH & 5010213 \\
\hline EG55 & Cesana & Second American Symphony & AFF & 5010371 \\
\hline EG56 & Mozart & Don Giovanni & $\mathrm{BH}$ & 5010411 \\
\hline EG57 & Moeran & $\begin{array}{l}\text { Lonely Waters (From Two Pieces } \\
\text { for Small Orchestra) }\end{array}$ & Novello & 5010226 \\
\hline
\end{tabular}




\begin{tabular}{|c|c|c|c|c|}
\hline EG58 & Moeran & $\begin{array}{l}\text { Whythorne's Shadow (From Two } \\
\text { Pieces for Small Orchestra) }\end{array}$ & Novello & 5010222 \\
\hline EG59 & Holst & $\begin{array}{l}\text { Egdon Heath (Homage to } \\
\text { Thomas Hardy): For Orchestra, } \\
\text { op. } 47\end{array}$ & Novello & 5009454 \\
\hline EG60 & $\begin{array}{l}\text { Handel } \\
\text { [arr. Beecham] }\end{array}$ & $\begin{array}{l}\text { The Faithful Shepherd = Il pastor } \\
\text { fido (Suite for Orchestra) }\end{array}$ & B \& H & 5010138 \\
\hline EG61 & Bantock & $\begin{array}{l}\text { Atalanta in Calydon (text } \\
\text { by Swinburne): A Choral } \\
\text { Symphony for Unaccompanied } \\
\text { Voices in Four Movements }\end{array}$ & $\mathrm{BRH}$ & 4972424 \\
\hline EG62 & Taylor & $\begin{array}{l}\text { Ramuntcho: Lyric Drama in } \\
\text { Three Acts (Seven Scenes) after } \\
\text { the novel by Pierre Loti, op. } 23\end{array}$ & J. Fischer & 5010121 \\
\hline EG63 & Maganini & $\begin{array}{l}\text { The Argonauts: A Californian } \\
\text { Tetralogy }\end{array}$ & AMC NY & 5010325 \\
\hline EG64 & Bach & Matthäuspassion & $\mathrm{BRH}$ & 5010059 \\
\hline EG65 & $\begin{array}{l}\text { Bach } \\
\text { [arr. Michaud] }\end{array}$ & $\begin{array}{l}\text { Chaconne: from the } 4^{\text {th }} \text { Sonata } \\
\text { for Violin Solo (arranged for } \\
\text { orchestra) }\end{array}$ & Cranz & 5010299 \\
\hline EG66 & Dumler & $\begin{array}{l}\text { Stabat Mater: for Solo Voices, } \\
\text { Chorus of Mixed Voices, } \\
\text { Orchestra and Organ, op. } 40\end{array}$ & J. Fisher & 5010387 \\
\hline EG67 & Wagner & $\begin{array}{l}\text { Die Walküre (English translation } \\
\text { by Frederick Jameson) }\end{array}$ & Schott & 5010687 \\
\hline EG68 & Wagner & Der fleigende Holländer & $\mathrm{BRH}$ & 5010427 \\
\hline EG69 & Pierné & $\begin{array}{l}\text { The Children's Crusade: A Musical } \\
\text { Legend in Four Parts (adapted } \\
\text { from the poem by Marcel } \\
\text { Schwob) [Vocal Score x 2] }\end{array}$ & Schirmer & 5010359 \\
\hline
\end{tabular}

Table 2. Goossens Scores/Yearbooks—Unlabelled, but with Clear Provenance

\begin{tabular}{|l|l|l|l|}
\hline Composer & Work & Publisher & NLA Bib ID \\
\hline Edgar Stillman-Kelley & $\begin{array}{l}\text { Gulliver: His Voyage to Lilliput: } \\
\text { Symphony in Four Movements }\end{array}$ & Affiliated Music Corp. & 7464640 \\
\hline Charles Cadman & $\begin{array}{l}\text { Dark Dancers of the Mardi Gras: } \\
\text { Fantasy for Orchestra and Piano }\end{array}$ & Affiliated Music Corp. & 7464455 \\
\hline Leuning, Otto & Two Symphonic Interludes & Affiliated Music Corp. & 7464568 \\
\hline Holbrooke & Overture: The Children of Don & Goodwin \& Tabb & 7464560 \\
\hline Grainger, Percy & $\begin{array}{l}\text { Tribute to Foster: For Five Single } \\
\text { Voices, Mixed Chorus, Musical } \\
\text { Glasses, Solo Piano, and Orchestra }\end{array}$ & Schirmer & 7464476 \\
\hline Schuman, [W.] & $\begin{array}{l}\text { Symphony No. 3 in Two Parts } \\
\text { (Four Movements) }\end{array}$ & Schirmer & 7464604 \\
\hline Grignon, Lamote de & Andalousie: tableau symphonique & Depôt Francisco Marti & 7464426 \\
\hline Casella, Alfredo & $\begin{array}{l}\text { La donna serpente: frammenti } \\
\text { sinfonici }\end{array}$ & Ricordi & 7464447 \\
\hline
\end{tabular}




\begin{tabular}{|l|l|l|l|}
\hline Tansman, Alexandre & $\begin{array}{l}\text { Concertino: pour piano avec accompa- } \\
\text { gnement d'orchestre }\end{array}$ & Max Eschig & 7464644 \\
\hline Tansman, Alexandre & $\begin{array}{l}\text { Deux moments symphoniques : pour } \\
\text { orchestre }\end{array}$ & Max Eschig & 7464649 \\
\hline Tansman, Alexandre & $\begin{array}{l}\text { Deux pièces : aria et alla pollacca : } \\
\text { pour orchestre }\end{array}$ & Max Eschig & 7464651 \\
\hline Mozart/Goossens & $\begin{array}{l}\text { Figaro dialogue: from the private } \\
\text { library of Eugene Goossens } \\
\text { (dialogue only) }\end{array}$ & MS & 4981115 \\
\hline $\begin{array}{l}\text { Cinccinati Symphony } \\
\text { Orchestra Yearbooks }\end{array}$ & 6 volumes & & $\begin{array}{l}\text { MUS } \\
\text { Goossens }\end{array}$ \\
\hline
\end{tabular}

Table 3. Possible Goossens Scores, Lacking Conclusive Provenance

\begin{tabular}{|l|l|l|l|}
\hline Composer & Work & Publisher & NLA Bib ID \\
\hline Liszt & Eine Faust-Symphonie & Schuberth & 4979984 \\
\hline Pierné & Poème symphonique pour piano et orchestre, op. 37 & MS & 4982611 \\
\hline Sibelius & Symfoni No. 6 & Abr. Hirschs Förlag & 4980121 \\
\hline Stanford & Songs of the Fleet: A Cycle of Five Songs, op. 117 & MS & 4999888 \\
\hline
\end{tabular}

\section{The EGC: A Hybrid Collection from Several Sources}

While researching the background of the EGC, I discovered two documents in the Symphony Services archives in Sydney that serve to clarify the disparate collections that have been amalgamated. The first is an undated valuation—possibly carried out in the late 1990s—of material formerly held by the South Australian National Music Library (SANML), referred to in the document as an 'Historic Collection,' listing fifty-two items. ${ }^{13}$ Most of these are now erroneously catalogued as part of the EGC, although they exhibit no discernible connection to Goossens. They consist predominantly of early operatic scores, and the inventory notes that some come from:

the personal library of William Saurin Lyster, conductor of a well-known touring opera company which existed from the 1850s to the 1890s. They contain his performance markings and cast lists. Another signature which appears is that of the donor, Fred Haines about who[m] little is known. ${ }^{14}$

It seems that the SANML 'historic collection' was moved to Sydney around the time of the devolution of the state orchestras (which occurred across Australian around the year 2000) and

\footnotetext{
${ }^{13}$ The undated, two-page document (pages numbered 20 and 21) is an extract from a larger document. It is likely that this 'historic collection' was only a part of a larger disbursement. See 'National Music Library Acquisition Records,' Box L4, Symphony Services Archive, offsite storage, Ultimo, NSW, Australia.

${ }^{14}$ Edward T. Garcia, 'Soldiers of the Queen-Bandmaster Frederick Haines,' Soldiers of the Queen, http: / / www.soldiersofthequeen.com/SouthAfrica-BandmasterFrederickHaines.html. Haines was born in London in 1870, appointed Bandsman in 1885, served in India from 1894 to 1896, and in the Anglo-Boer War in South Africa from 1900 to 1903 . Haines and his family moved to New South Wales in 1911. According to a 1933 article in the Sydney Morning Herald, 'Mr Haines was a one-time conductor and bandmaster of HM Light Guards [London]. He has been adjudicator in many important eisteddfods, both in England and Australia, and is now a member of both the A.B.C. Symphony Orchestra and the A.B.C. Military Band in Sydney.' See 'Composers: Competition Awards: Seven Sydney Prize-Winners,' Sydney Morning Herald, 20 July 1933, 9.
} 
maintained by Symphony Australia, presently known as Symphony Services International. The valuation document states that the SANML held thirty boxes of historical items, and that half of the boxes were 'intensively sampled,' producing an inventory of fifty-two items. The inventory provides only brief descriptors, but the dates, publishers, and other details (such as the condition of bindings) link almost the entire collection (forty-nine out of fifty-two items) to volumes now in the EGC. This is reproduced in Table 4, with the items listed in the order given in the inventory.

Table 4. The SANML 'Historic Collection' (Sampling Fifty-two Scores), Including Market Valuation and Relevant NLA Bib ID Numbers

\begin{tabular}{|c|c|c|c|c|c|}
\hline Composer & Work & Condition/Date & Publisher & $\begin{array}{l}\text { Value } \\
\text { (\$) }\end{array}$ & $\begin{array}{l}\text { NLA Bib } \\
\text { ID }\end{array}$ \\
\hline Bach & Kammermusik & Fair & Bach Gesellschaft & 180 & 4975670 \\
\hline Bellini & I Puritani & Good. Cuts by Lyster & Pacini & 200 & 4971162 \\
\hline Bellini & La Sonnambula & Poor & Ricordi & 50 & 4972943 \\
\hline Donizetti & La Favorita & Good 1840s & Schlesinger & 100 & 4972549 \\
\hline Donizetti & Lucrezia Borgia & Third act only, good & M.S. & 80 & 4973208 \\
\hline Auber & Fra Diavolo & 1846-1854 & Brandus & 120 & 4975756 \\
\hline Balfe & The Rose of Castile & Lyster's markings & $\begin{array}{l}\text { Cramer, Beale \& } \\
\text { Chappell }\end{array}$ & 200 & 4972775 \\
\hline Balfe & The Enchantress & 1849. Lyster. Fair & Chappell & 140 & 4975885 \\
\hline $\begin{array}{l}\text { Bach [ed. } \\
\text { Bartholemew] }\end{array}$ & 6 Motets & Fair & Ewer & 80 & 4975736 \\
\hline $\begin{array}{l}\text { Bach ed. Bar- } \\
\text { tholemew }\end{array}$ & Christmas Oratorio & & Bach Gesellschaft & 200 & 4972749 \\
\hline Benedict & Lily of Killarney & Lyster (?). good & n.p. & 180 & 4972856 \\
\hline Debussy & $\begin{array}{l}\text { Prélude à l'après- } \\
\text { midi d'un faune }\end{array}$ & & MS & 30 & 4971008 \\
\hline Costa & Eli & Fair & Lamborn & 70 & 4972980 \\
\hline Gay & Beggar's Opera & $\begin{array}{l}\text { Special edition, } 1921 . \\
\text { Good }\end{array}$ & Heinemann & 150 & 4972070 \\
\hline Handel & Esther & V. early & n.p. & 150 & 4977881 \\
\hline $\begin{array}{l}\text { Bach/ } \\
\text { Lovelock }\end{array}$ & $\begin{array}{l}\text { Prelude and } \\
\text { Fugue }\end{array}$ & 'For Joseph Post' & MS & 150 & - \\
\hline Handel & Joshua & Early, good & n.p. & 200 & 4976635 \\
\hline Handel & Judas Maccabeus & $\begin{array}{l}\text { Early, spine partly } \\
\text { detached. fair }\end{array}$ & $\begin{array}{l}\text { Burton \& Whit- } \\
\text { taker }\end{array}$ & 200 & 4981820 \\
\hline Handel & Judas Maccabeus & Spine detached, early & Randall & 250 & 4982323 \\
\hline Handel & Judas Maccabeus & 1.866 (1866?) & $\begin{array}{l}\text { Handel Soc. } \\
\text { Leipzig }\end{array}$ & 180 & 4981820 \\
\hline Handel & Il Radamisto & Good, rebound 1720 & Richard Meares & 450 & 49776636 \\
\hline
\end{tabular}




\begin{tabular}{|c|c|c|c|c|c|}
\hline Handel & Rodelinda & $\begin{array}{l}\text { Rebound, good, v. } \\
\text { early }\end{array}$ & Auer & 350 & 4981586 \\
\hline Handel & $\begin{array}{l}\text { Ode for St Cecilia's } \\
\text { Day }\end{array}$ & Fair, 1844 & $\begin{array}{l}\text { Handel Soc. Cra- } \\
\text { mer Beale }\end{array}$ & 150 & - \\
\hline Handel & Julius Caesar & $\begin{array}{l}\text { Partly disbound fair } \\
1723\end{array}$ & n.p. & 200 & 4981850 \\
\hline Handel & Samson & Good, 1853 & $\begin{array}{l}\text { Handel Soc. Cra- } \\
\text { mer Beale }\end{array}$ & 150 & 4977673 \\
\hline Handel & Sosarme & Good, 1732 & n.p. & 400 & 4320362 \\
\hline Handel & Samson & C19, good & Novello Ewer & 180 & 49764428 \\
\hline Handel & Samson & $\begin{array}{l}\text { Fair, boards detached, } \\
\text { early }\end{array}$ & n.p. & 400 & 4976414 \\
\hline Handel & Semele & Early & n.p. & 120 & 4977651 \\
\hline Liszt & Faust Symphony & Untidy & Schuberth & 60 & 4979984 \\
\hline King & Centennial Cantata & Melb. 1888 & Glen \& Co & 150 & 746639 \\
\hline Mendelssohn & St Paul & Good PB & B \& Hartel & 80 & 4975899 \\
\hline Mendelssohn & St Paul & Good HB & B \& Hartel & 140 & \\
\hline Handel & Susanna & Early, good, rebound & n.p. & 240 & 4976064 \\
\hline Meyerbeer & L'Africaine & $\begin{array}{l}\text { Possibly first, fair, } \\
\text { interpolated MS pages } \\
\text { (possibly by Lyster) }\end{array}$ & Boosey \& Co & 350 & 4981913 \\
\hline Meyerbeer & Robert le diable & Ugly boards, good & Schlesinger & 180 & 4982014 \\
\hline Meyerbeer & Il profeta & Good & Ricordi & 100 & 4976012 \\
\hline Honegger & King David & Paper bound, good & Foetisch & 120 & 4980677 \\
\hline Gounod & Faust (Margarethe) & Fair & Bote \& Bock & 100 & 4974895 \\
\hline Haydn & Scots Songs & Before 1800 , good & William Napier & 400 & - \\
\hline Handel & $\begin{array}{l}\text { Judas Maccabeus } \\
\text { et al. }\end{array}$ & $\begin{array}{l}8 \text { vols, poor, cover } \\
\text { detached }\end{array}$ & Novello & 45 & 4981841 \\
\hline Handel & Messiah & $\begin{array}{l}\text { Large folio, 1859, } \\
\text { signed Joseph Post, } \\
\text { disbound }\end{array}$ & Novello & 40 & 4981738 \\
\hline Handel & $\begin{array}{l}\text { Instrumental } \\
\text { Music } \\
\end{array}$ & Fair & $\begin{array}{l}\text { Handel Ge- } \\
\text { sellschaft }\end{array}$ & 100 & 4976078 \\
\hline Handel & Acis and Galatea & 1846, good & Handel Society & 250 & 4975348 \\
\hline Handel & L'Allegro et al. & V. good & n.p. & 350 & 4975229 \\
\hline Handel & Aggripina & $\begin{array}{l}\text { Good, v. early, spine } \\
\text { detached }\end{array}$ & n.p. & 400 & 4975310 \\
\hline Handel & Alexander's Feast & $\begin{array}{l}\text { V. early 1736?, Ugly } \\
\text { boards, good }\end{array}$ & n.p. & 300 & 4975027 \\
\hline $\begin{array}{l}\text { Handel [ed. } \\
\text { Mendelssohn] }\end{array}$ & Israel in Egypt & Fair & Novello, Ewer & 120 & 4974966 \\
\hline
\end{tabular}




\begin{tabular}{|l|l|l|l|l|l|}
\hline $\begin{array}{l}\text { Handel [ed. } \\
\text { Mendelssohn] }\end{array}$ & Israel in Egypt & Good & Novello, Ewer & 180 & 4974961 \\
\hline Handel & Jeptha & Good & Handel Soc. & 200 & 4976032 \\
\hline Handel & Athalia & $\begin{array}{l}\text { Fair, front cover } \\
\text { detached, early }\end{array}$ & n.p. & 80 & 4975291 \\
\hline Handel & Belshazzar & Good, v. early, rebound & n.p. & 150 & 4978068 \\
\hline TOTAL & $\mathbf{5 2 ~ I t e m s ~}$ & & & $\mathbf{\$ 9 2 1 5}$ & \\
\hline
\end{tabular}

The Lyster scores in this inventory tally exactly with the corresponding scores in the EGC. Further confirmation of the merging of these collections is provided by a score of Handel's Messiah, which the SANML inventory notes is signed by Joseph Post. The NLA catalogue [4981738] indicates that its EGC Messiah score (same date and publisher) is inscribed: Joseph M. Post Melb[ourne]. 1938, with a further inscription: 'Fred Haines, Late First Life Guards, London, England,' linking both collections with the EGC, and introducing the former owner of much of the SANML collection, Fred Haines.

It is clear that the EGC encompasses not only the GC, but also other historical scores from the Symphony Australia Library. This creates confusion around the Goossens material, and compromises other items that are of significance in their own right, such as the Lyster scores, which provide important insights into the practices of nineteenth-century opera companies in Australia. While such material remains under the umbrella of the EGC, it occupies an uncertain netherworld between owners and attributions.

A further subset of the EGC comprises scores that were recognised as possessing significance in relation to the $\mathrm{ABC}$ orchestras. For example, a score of Arthur Honegger's King David (1921) in the SANML inventory is almost certainly now in the EGC. The SANML material was subsequently merged with the Goossens scores as the NLA acquisition was being prepared. ${ }^{15}$

\section{Goossens' Scores (GC 1-69) and Other Material with Clear Provenance}

Of the 183 items currently catalogued in the EGC, eighty were undoubtedly part of Goossens' personal library. Some items were previously catalogued by the ABC Music Library, labelled 1-69, and marked 'EG.' This subset corresponds to the second document discovered in the Symphony Services Archive, which is reproduced in Table $1 .{ }^{16}$ No earlier inventory has been located, although the labels (1-69) appear to date from the 1960s or earlier. In addition to these labels, most items bear inscriptions, stamps, or signatures that further confirm their provenance. The inventory notes that one score—Gershwin's Lullaby (1919, EG17)—had been lost. It is unclear why only sixty-nine works were catalogued as there are twelve additional items (shown in Table 2) that clearly formed part of the Goossens acquisition in 1956.

A selection of the most significant items in Tables 1 and 2 are described below, revealing the synergies that emerge between the works, their composers, and the place they occupied in

\footnotetext{
${ }^{15}$ R1, 'Reference and archival material,' National Music Library Acquisition Records, Box L4, Symphony Services Archive, offsite storage, Ultimo. Pages 365-73 of R1 list an inventory titled 'Eugene Goossens Collection' of 'Rare Old Scores Ref. \# 49,' which refers to many of the scores from the SANML, along with others from unknown sources.

${ }^{16}$ R1, 'Reference and archival material,' Symphony Services Archive, 289-91. Dated May 2000, the inventory was likely a stocktake made in preparation for removal to NLA.
} 
Goossens' career. This analysis will also establish categories within the collection, against which other scores of uncertain provenance will be considered. For these purposes the collection is categorised as follows: (a) works by American composers (by birth or adoption); (b) works by British composers; (c) works by twentieth-century European and Soviet composers; (d) pre-twentieth century works; (e) operatic works.

\section{American Composers Represented in the GC}

The composers represented here were all Goossens' contemporaries, most of whom crossed paths with him professionally during the two decades that he held important posts in America, with the Rochester Philharmonic Orchestra—of which he was the founding conductor-and the Cincinnati Symphony Orchestra (CSO)—where he succeeded Fritz Reiner (1888-1963). All the scores are personally inscribed to the conductor, and the occasional use of the byname 'Gene' reveals composers who were closer acquaintances.

The best-known American composer represented is Aaron Copland (1900-1990), with Two Pieces for String Orchestra (EG50), serving as a reminder that Goossens commissioned Fanfare for a Common Man from him in 1942. Several members of the CSO had been drafted into the armed services in that year and, in response, Goossens invited a group of American composers to write short fanfares with patriotic titles, as 'a stirring and significant contribution to the war effort. ${ }^{17}$ In all, twenty-three composers responded to the invitation, with Goossens himself contributing Fanfare for the Merchant Marine..$^{18}$ The line-up of composers resembles a 'who's who' of the times, although only Copland's fanfare is remembered today.

Another, largely self-taught composer who took part in this fanfare project was Paul Creston (1906-1985), represented by Partita (EG51), who was notable for having 'introduced such alien time signatures as 6/12 and 3/9.' ${ }^{19}$ In 1945 Goossens again invited Copland and Creston to take part in a further multi-composer work of his own devising, Variations on an Original Theme, along with William Grant Still (1895-1978), Deems Taylor (1885-1966), Howard Hanson (1896-1981), and William Schuman (1910-1992). ${ }^{20}$ Goossens regularly conducted the work of Schuman who is represented by his American Festival Overture (EG1), and Symphony No. 3 [7464604]. Taylor, represented by Ramuntcho (EG62), is best remembered for his appearance in Disney's Fantasia (1940), as the Master of Ceremonies. Hanson became Director of the Eastman School of Music at the age of 24 and was well established there by the time Goossens took up his post in Rochester. Goossens taught at the Eastman School, and the two men were well acquainted. Hanson is represented by his Symphony No. 3, op. 33 (EG48). Also active at the Eastman Conservatory during Goossens' tenure was Otto Leuning (1900-1996) whose Two Symphonic Interludes [7464568] are in the collection.

Of lesser-known composers, Frances Ulrich Cole (1905-1992) was a founding member of the Society of American Woman Composers and visited Goossens in Australia, as confirmed by an inscribed score of her Divertimento for Piano and String Orchestra (EG27), dated 18 May 1953, Sydney. John Haussermann (1901-1986), a successful composer born with cerebral palsy,

\footnotetext{
${ }^{17}$ Rosen, The Goossens, 235.

${ }^{18}$ Rosen, The Goossens, 235.

${ }^{19}$ Nicolas Slominsky, Music since 1900, 5th ed. (New York: Schirmer, 1994), 951.

${ }^{20}$ Goossens recorded Still's Symphony No. 3 with the London Symphony Orchestra in 1962; Rosen, The Goossens, 245.
} 
is represented by his Concerto for Voice and Orchestra, op. 25 (EG33). Goossens conducted his First Symphony in Cincinnati, the third movement of which was an elegy inspired by the death of Ravel. ${ }^{21}$ Edgar Stillman-Kelley (1857-1944), the elder statesman among these composers, inscribed his Gulliver: His Voyage to Lilliput [7464640]: 'To my friend Eugene Goossens, the great conductor-composer who has honoured his octogenarian admirer by accepting the dedication of this work.' Goossens premiered Gulliver in Cincinnati in 1937. Charles Cadman (1881-1946), composer of At Dawning, which became a perennial drawing room favourite during the $1920 \mathrm{~s}^{22}$ is represented here by Dark Dancers of the Mardi Gras: Fantasy for Orchestra and Piano [7464455].

A number of the composers represented were associated with film, Broadway, and popular music, many cultivating double musical identities, composing 'serious music' for the concert hall alongside their more lucrative commercial work. Film composers include Gerard Carbonara (1886-1959) (EG28) and Otto Cesana (1899-1980) (EG55), the latter of whom was a composer and conductor active as an arranger and orchestrator for the Radio City Music Hall in New York. Bernard Kaun (1899-1980) (EG19) was a composer and orchestrator for Universal Horror Pictures, working notably on the film Frankenstein (1931). Eric DeLamarter (1880-1953) was associate conductor of the Chicago Symphony Orchestra during the 1930s, and appeared as an actor in the 1946 film, Humoresque. He is represented by the novelty The Black Orchid: Concert Suite Drawn from Music for a Highly Stylized Ballet-Satire (EG18).

Composers associated with Broadway include Hans Spialek (1894-1983)—represented by Sinfonietta (EG35) - a Viennese born, American composer, who was taken prisoner by the Russians during World War One, and eventually studied composition under Reinhold Glière. He was well known for his orchestrations of Broadway musicals by Cole Porter and Rodgers and Hart. Alexander Steinert (1900-1982) (EG34) studied composition at the Paris Conservatoire and was a conductor who occasionally acted in films, as well as a composer and arranger of the music for the 1941 Disney film Bambi, ${ }^{23}$ along with around 150 Broadway musicals. ${ }^{24}$ Frederick Jacobi (1891-1952) (EG40 \& 41) came from a multifarious musical background which, alongside composing, included working as a jazz saxophonist and also as prompter at the Metropolitan Opera, New York. Several composers held positions with leading American orchestras, among them Michel Gusikoff (1893-1978) (EG7), who spent a period as concertmaster of the Philadelphia Orchestra under Leopold Stokowski, later becoming concertmaster of the New York Symphony. Arcady Dubensky (1890-1966) (EG11) was born in Russia where he established himself as a composer and violinist in the Moscow Imperial Opera Orchestra until the Revolution caused him to flee. He then spent time in Constantinople, where he was a pianist in various hotels until he reached the USA, settling in New York in 1921, where he worked as a professional violinist, first in the New York Symphony Orchestra and later the New York Philharmonic Orchestra. ${ }^{25}$

\footnotetext{
${ }^{21}$ Slominsky, Music since 1900, 460.

22 Slominsky, Music since 1900, 520.

23 'Alexander Steinert Papers,' New York Public Library Archives and Manuscripts, http: / / archives.nypl. org/mus/ 20410.

${ }^{24}$ George J. Ferencz, 'Hans Spialek,' Grove Music Online, https: / / www.oxfordmusiconline.com.

25 'Arcady Dubensky (Composer, Arranger),' Bach Cantatas Website, https:/ / www.bach-cantatas.com/ Lib/Dubensky-Arcady.htm.
} 
Other composers and arrangers from more academic backgrounds with scores in the collection include the composer, musicologist and writer Everett Helm (1913-1999) (EG8), who spent much of his career in Germany. Martin Dumler (1868-1958) (EG66) was known to Goossens through his work as a choral conductor and as president of the Bruckner Society in Cincinnati. A. Walter Kramer (1890-1969) was a music publisher and composer who worked on the staff of Musical America and became managing director of the Galaxy Music Corporation in 1936. He is represented by a score of Bach's 'O Mensch, bewein' dein' Sünde gross' (EG9) transcribed for string orchestra. ${ }^{26}$

This eclectic group of works highlights Goossens' wide-reaching musical tastes along with his untiring interest in new music and support for contemporary composers from diverse backgrounds. The collection reflects a strong interaction between contemporary composers and conductors of leading orchestras in America during this period, and highlights the intersection of career paths between composers, conductors, orchestral musicians, and the world of commercial music. Goossens maintained a thirst for new compositions and explored the latest developments in music wherever he was working. During his tenure in Australia, Goossens was supportive of Australian composers, notably John Antill (1904-1986), and created a concert suite from the composer's ballet Corroboree (1946), ${ }_{1}^{27}$ which he went on to champion both in Australia and abroad, recording the work with the SSO in 1950 and with the London Symphony Orchestra in $1958 .{ }^{28}$

\section{British Composers in the GC}

Goossens' autobiography, Overture and Beginners, details his life up until around 1931, affectionately describing his youth in London and his formative years as a violinist, composer, and an emerging conductor during the early decades of the twentieth century. Goossens was acquainted with a wide circle of English composers, whose music he continued to perform and record throughout his career. It is easy to forget that there was a time when the Colour Symphony of Arthur Bliss (1891-1953) (EG 53) or the symphonies and tone poems of Arnold Bax (1883-1953) (EG2 \& 47) were considered challenging modern works, verging on the avant-garde. The collection also includes works by composers who have roots in the nineteenth century, for example Granville Bantok (1868-1946) (EG52 \& 61), who conducted the first orchestral concert Goossens attended, aged six. ${ }^{29}$ Another prolific composer from that period who has all but disappeared from the repertoire is Josef Holbrooke (1878-1958), who was associated with Goossens during his years in London, and whose works the conductor recorded, ${ }^{30}$ referring to him as 'the redoubtable Josef Holbrooke, the most prolific, and alas! to-day the least played of all that older generation of living British composers. ${ }^{31}$

\footnotetext{
${ }^{26}$ 'Arthur Walter Kramer (Composer, Arranger),' Bach Cantatas Website, https: / / www.bach-cantatas.com / Lib/Kramer-Arthur-Walter.htm.

${ }^{27}$ A microfilm of the manuscript is in the NLA collection [625340].

${ }^{28}$ Corroboree Ballet Suite, Sydney Symphony Orchestra/Goossens, rec. 5 Dec. 1950, Sydney. 2 x 12 " 78 rpm discs, HMV ED1193-4 (1950), reissued on Dutton compact disc CDBP 9779 (2007); Corroboree Ballet Suite, London Symphony Orchestra/Goossens rec. 24 Aug. 1958, London. Omega Record Group, Inc. compact disc reissue EVC 9007 (1994), of original Everest LP (SDBR 3003).

${ }^{29}$ Eugene Goossens, Overture and Beginners: A Musical Autobiography (London: Methuen \& Co., 1951$), 41$.

${ }^{30}$ Goossens, Overture and Beginners, 137, 167, 181, 191.

${ }^{31}$ Goossens, Overture and Beginners, 137.
} 
The score of Introduction and Allegro (EG45) by Edward Elgar (1857-1934) has had an uncertain posthumous history. For some years it was on display outside Goossens Hall in Ultimo, Sydney, which was opened in 1991 (a significant step in acknowledging the legacy of the conductor whose name had been all but erased from Australian musical life after his departure). Several scores from the GC were placed on public display next to a portrait of Goossens at the time the Hall was opened. The conductor's biographer, Carole Rosen describes the confusion over this score:

Pride of place is given to Elgar's Introduction and Allegro ... inscribed: 'To my friend and guardian angel. With affectionate good wishes.' It is dated 1905 when Eugene would have been all of twelve years old! ... On closer perusal the dedicatee appears to be Griffiths rather than Goossens! $!^{32}$

This is only partly correct; the NLA catalogue entry identifies the dedicatee as Lyden Gaffer, but there is a further inscription on the endpapers that reads 'For Gene, in admiration and affection,' followed by an indecipherable signature, almost certainly not Elgar's. Clearly the score belonged to Goossens, but it is unclear how it found its way into his personal library.

Other composers in the collection include Goossens himself, with a pocket score of his String Quartet No. 2 [1924279], inscribed to his third wife, Marjorie. Percy Grainger's (1882-1961) inscribed Tribute to Foster [7464476] score serves as a reminder of the long-standing friendship between the two men from their early days in London-Goossens often programmed Grainger's music in Australia, America, and England. ${ }^{33}$ Alongside works by Gustav Holst (1874-1934) (EG59 \& 49) and E.J. Moeran (1894-1950) (EG57 \& 58) that the conductor regularly performed, is the virtuosic and influential Violin Concerto (EG43) by William Walton (1902-1983), with the solo part edited by Jascha Heifetz. The violinist made the first recording of the concerto with the CSO under Goossens in 1942. ${ }^{34}$

The British works in the collection represent only a small portion of those that Goossens engaged with during his career. Goossens spent the first thirty years of his life in London, and his formative musical influences and friendships stem from that culture. These scores commemorate the composer's longstanding commitment to British music and point to the British composers that Goossens was closest to, musically and personally.

\section{Twentieth-century European and Soviet Composers}

A number of the European composers represented in the collection are only minor names today, such as the Spaniards Óscar Esplá y Triay (1886-1976) (EG12 \& 13), J. Lamote de Grignon (1872-1949) [7464426] and Jaume Pahissa (1880-1969) (EG37). Goossens conducted in Spain on numerous occasions, notably in Barcelona, at the invitation of Sergei Diaghilev, ${ }^{35}$ where he likely made the acquaintance of these figures. Alfredo Casella (1883-1947) and Goossens were friends, ${ }^{36}$ and two volumes in the collection entitled La Donna serpente: frammenti sinfonici [7464447] comprise selections from his opera of the same title.

\footnotetext{
${ }^{32}$ Rosen, The Goossens, 414.

${ }^{33}$ Grainger appears under British composers on the basis that he belonged to Goossens' circle in London in the early part of the twentieth century.

${ }^{34}$ David Patmore, 'Eugene Goossens,' Naxos Classical Music, 2007, https:/ / www.naxos.com/person/ Eugene_Goossens_16377/16377.htm.

${ }^{35}$ Goossens, Overture and Beginners, 229.

${ }^{36}$ Goossens, Overture and Beginners, 146, 147, 223; Rosen, The Goossens, 307.
} 
The Franco-Polish composer Alexandre Tansman (1897-1986) [7464644; 7464469; 7464651] was also a virtuoso pianist who toured widely in Europe, Britain, and America. The 1931-1932 season in Cincinnati included a performance of Tansman's Piano Concerto No. 2 (described as 'a musical biography of Charlie Chaplin') conducted by Goossens. ${ }^{37}$ Gabriel Pierné (1863-1937) (EG69) was, in his day a well-known conductor and composer, much admired by Goossens, who programmed his Children's Crusade in the Cincinnati May Festival of 1931, describing the performance 'with some 600 children ... which remains the most moving thing I ever heard in a concert hall. ${ }^{38}$ In addition to conducting the Children's Crusade in Australia, ${ }^{39}$ Goossens led the Australian premiere of Pierné's orchestration of the César Franck (1822-1890) Prelude, Chorale and Fugue (SSO, Sydney, 1947). ${ }^{40}$ Also rarely programmed today is Eric Werner (1901-1988), a Viennese composer of Jewish background, whose works Goossens performed in Cincinnati. His transcription for orchestra of Mozart's KV 608, Fantasy for a Musical Clock (EG21), was for many years popular in concerts of the light classics in the US. Werner's inscription reads 'To Mr Eugene Goossens, the great conductor, the fine composer, the kind man, in deep gratitude, Eric Werner.'

The score of Rhapsodie flamande (ca 1931) (EG29) by Michel Brusselmans (1886-1960) contains the inscription: 'To Eugène Goossens from Jean Michaud as a souvenir of our first meeting, 10th September 1931.' Michaud (1884-1961) can best be described as an author, composer, violinist, and occultist of Dutch origin. ${ }^{41}$ In addition to this souvenir of his first meeting with Goossens, the collection contains Michaud's own orchestration of J.S. Bach's Chaconne (EG65), also inscribed. The connection between Goossens and Michaud brings us unexpectedly into the world of the occult, which held a fascination for Goossens throughout his life. Michaud was the author of several books on the occult and spiritualism, one of which bears the intriguing title: Symphonie Fantastique: Diablerie in Four Movements or a Symphony in Words, ${ }^{42}$ a work completed in 1942, and set 427,000 years in the future. There are connections between these byways and Goossens' own magnum opus The Apocalypse (1953), a work imbued with mysticism and spiritualism that also veers towards the darker themes of the conductor's life.

The collection contains scores of three major twentieth-century composers whose works held particular significance for Goossens at different points in his career. Arnold Schoenberg's Fünf Orchesterstücke, op. 16 (EG46) was first conducted by Goossens on 9 November 1921 at the Queen's Hall in London with his own orchestra. Schoenberg's work requires enormous forces, and this performance was a strategic gesture aimed at showcasing the conductor's prowess as an interpreter of the most complex modern music. Some years earlier, Goossens had played the work as a violinist in a performance conducted by Henry Wood, an experience he notes in his autobiography, quoting the Daily News review of the concert: 'we must be content with

\footnotetext{
${ }^{37}$ Rosen, The Goossens, 147.

${ }^{38}$ Goossens, Overture and Beginners, 292.

${ }^{39}$ Denham Ford, 'Sir Eugene Goossens. May 261893 - June 13, 1962,' Le Grand Baton: Journal of the Sir Thomas Beecham Society 26/2, no. 67 (1995): 8.

${ }^{40}$ Phillip Sametz, Play On! 60 Years of Music-making with the Sydney Symphony Orchestra (Sydney: ABC Books, 1992), 365.

${ }^{41}$ Suzanne Michaud, 'Jean Michaud-Publisher Extraordinary,' Delius Society Journal 143 (2008): 127-31.

${ }^{42}$ Jean Michaud, 'Symphonie Fantastique: Diablerie in Four Movements or a Symphony in Words,' Occult Mysteries: The Path to the Light, http: / / www.occult-mysteries.org/symfan/symphonie-fantastique-intro. html.
} 
the composer's own assertion that he has depicted his own experience, for which he has our heartfelt sympathy. ${ }^{43}$ Goossens maintained this work in his repertoire for some years, and reviews of later performances suggest that critical appreciation of Schoenberg's work did not improve during the ensuing decades. ${ }^{44}$

Symphony No. 7 by Dmitri Shostakovich (1906-1975) (EG44, 3 copies) achieved quite a different reception to Schoenberg's work, becoming a musical catchcry for the War effort early on. One copy (' 3 ') is inscribed to Goossens from Shostakovich and dated 17 October 1943 and is presumably a posthumous token of the composers' appreciation for Goossens' performances in Cincinnati in the 1942-1943 season. ${ }^{45}$ The Symphony had its premiere on 5 March 1942 in the Soviet Union, and the American premiere followed closely after, led by Toscanini on 19 July 1942. The work was widely taken up in America and Goossens' performances in Cincinnati, shortly after those of Toscanini, were timely. Although Shostakovich did not feature strongly in Goossens' repertoire, the conductor did give the first Australian performance of the composer's Sixth Symphony in 1952 with the SSO. ${ }^{46}$

Throughout his career Goossens was closely associated with the music of Igor Stravinsky (1882-1971), of which he was a tireless champion. Goossens effectively launched his concert career in London with the 'Goossens Orchestra' on 7 June 1921 with the first concert performance in England of The Rite of Spring (1913). This occasion was of considerable significance considering the dual identities that the work has subsequently acquired, both as a ballet and as a concert showpiece. The EGC includes a staple of Goossens' repertory, Stravinsky's Firebird Suite (1919) (EG42) marked in considerable detail and inscribed by the composer in New York in 1945. In Australia, Goossens chose the Firebird Suite for his SSO debut in June $1946,{ }^{47}$ in addition to giving performances in Perth and Adelaide in June and July 1946. He also conducted the following Australian premieres of Stravinsky's works: The Rite of Spring (SSO, 23 August 1946); Apollon musagète (SSO, 1949); Symphony in Three Movements (SSO, 1951); Song of the Nightingale (SSO, 1952); and Symphony in C (SSO, 1955). ${ }^{48}$

\section{Pre-twentieth Century Works}

The collection contains scores of Ludwig van Beethoven's Second, Fifth, and Sixth Symphonies (EG23 \& 24). The Second and Fifth are not marked, while the Sixth is, though not in Goossens' hand. Beethoven's Second Symphony was recorded by Goossens with the SSO, and arguably remains one of the finest testaments to his decade in Australia. ${ }^{49}$

Another score of significance is Sir Thomas Beecham's (1879-1961) arrangement of Handel's Il Pastor Fido (1712) (EG60), which serves as a reminder of Goossens' close association with the elder conductor, who had helped to launch his career in London in 1915. Both Beecham and Goossens indulged in the practice of editing and re-orchestrating music of the more distant past, culminating in Goossens' luxurious orchestration, commissioned by Beecham, of Handel's Messiah (1959). This version was, for many years, unavailable for performance,

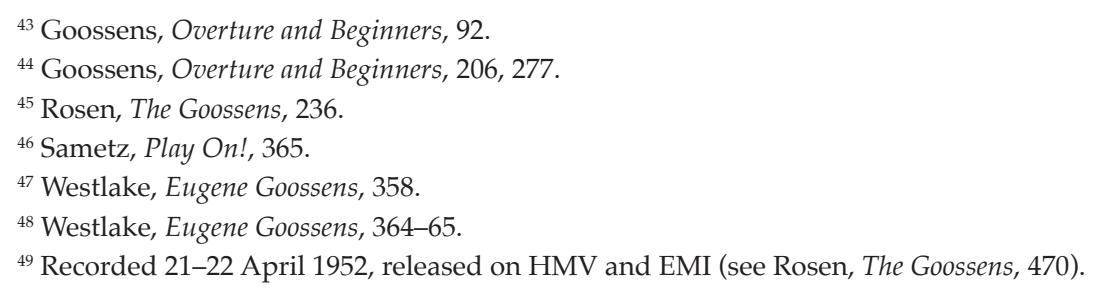


although Beecham's recording has become a classic. ${ }^{50}$ Beecham's widow refused to allow access to the score, fuelling the widely reported rumour that the work was orchestrated by Beecham rather than Goossens. The material in the NLA was obtained for performances in Australia in 1980, and a study of the reproduction of the manuscript score clearly confirms Goossens' authorship. While not a part of the EGC, the score and orchestral materials [7464742] are an important NLA resource for Goossens research.

\section{Operatic Works in the GC}

As well as being from the third generation of a family of operatic conductors, Goossens was the composer of two operas: Judith (1926-1929) and Don Juan de Mañara (1930-1935), both with libretti by Arnold Bennett. His autobiography contains an insider account of the interdynastic significance of marked conductor's scores in the development of his career, where he describes his developing prowess as an opera conductor during the First World War, when he worked as Beecham's assistant, taking over performances of major operas without orchestral rehearsal. He notes that:

By a strange coincidence, the conductor's scores at these performances (loaned by Ricordi) were those used by my grandfather and father at the productions they conducted with the Carl Rosa Company respectively fifteen and twenty-five years earlier ... It always gave me a strange emotion to encounter their two familiar pencil markings; often I was constrained to add my own to keep the three-generation record straight. ${ }^{51}$

While Eugene III's musical heritage hailed from long-established operatic roots, he was the first to distinguish himself equally in the fields of ballet and symphonic music. As previously mentioned, Goossens had been conductor of the Philharmonic Orchestra in Rochester and taught at the Eastman School of Music, as well as acting as the Music Director of the Rochester American Opera Company. ${ }^{52}$ On arriving in Sydney, he created a similar power base, as Chief Conductor of the SSO and Director of the SCM, where he presented a wide repertoire of operas, effectively dominating the operatic scene in Sydney at that time. ${ }^{53}$ At the Conservatorium, Goossens created enterprising opera seasons that included a production of his own Judith (1927), featuring a young Joan Sutherland in the title role. Other productions included Pelléas et Mélisande (1902) and Die Meistersinger von Nürnberg (1867) in abridged versions, a practice that hailed back to his days as a touring opera conductor in the United Kingdom. Further insights into Goossens' practices are preserved in a file of typed dialogue for Mozart's The Marriage of Figaro (1786) [4981115]. This dialogue was used for performances at the SCM, replacing Mozart's own recitatives, an old-fashioned practice, even by the standards of the 1950s. This dialogue may have been based upon that used for Beecham's performances in London in 1917, which Goossens took over, noting in his autobiography that 'witty dialogue-most authentically Beaumarchais—-took the place

\footnotetext{
${ }^{50}$ Handel, Messiah, Jennifer Vyvyan, Monica Sinclair, Jon Vickers, Giorgio Tozzi, Royal Philharmonic Chorus, Royal Philharmonic Orchestra, cond. Thomas Beecham. RCA Victor, 4 x 12" LP discs, LD 6409, HMV (1959).

${ }^{51}$ Goossens, Overture and Beginners, 120-21.

${ }^{52}$ Otto Luening, 'Goossens at Eastman,' Le Grand Baton: Journal of the Sir Thomas Beecham Society 26/2, no. 67 (1995): 10.

${ }^{53}$ He engaged a number of non-student singers and musicians to make productions of large-scale works possible, a practice for which he was soundly criticised by the musical establishment at the Sydney Conservatorium, which resented the mixture of professional and student singers being used.
} 
of unintelligible gabble that usually passes for Mozartian recitative and gave the work a dramatic continuity usually lacking in the average performance. ${ }^{\prime 54}$

Operatic scores in the EGC with Goossens provenance include Die Walküre (1870) (EG67), which he conducted at the SCM, and Der fliegender Holländer (1843) (EG68), which he conducted in Brisbane. The Walküre score contains pencilled cuts and emendations, and the Holländer score, in addition to internal cuts, has typed instructions affixed to the front cover written by Goossens in preparation for his arrival in Brisbane.

\section{The Cincinnati Symphony Orchestra Yearbooks}

Goossens was the conductor of the CSO between 1931 and 1946. When he moved to Sydney, he brought with him bound yearbooks (incomplete) from the period of his tenure. These were for many years used as references by the staff of the $\mathrm{ABC}$ /Symphony Australia and are seminal resources for the study of Goossens' career in Cincinnati. The six volumes (see Table 2) cover the thirty-second season (1926-1927) when Reiner was still conductor of the orchestra, followed by the thirty-eighth and thirty-ninth seasons (1933-1934); the forty-second to forty-fourth seasons (1936-1939); the forty-ninth (1943-1944) and the fifty-first seasons (1945-1946). While these yearbooks are not catalogued within the GC, their provenance is without question.

\section{Symphonic Scores}

We now consider four scores of uncertain provenance that do not bear any inscriptions or annotations that would directly connect them with Goossens. It was decided to sample these items and establish any links they might have to the conductor. The evidence gathered makes it difficult to discount that they may have been part of Goossens' library. Other scores within the EGC of unresolved provenance may produce similar inconclusive results, exposing grey areas between the subsections of the collection.

Franz Liszt's Eine Faust-Symphonie (1857) [4979984] received its Australian premiere with the SSO on 18 April 1950, conducted by Goossens. ${ }^{55}$ The score of the work in EGC is of great interest due to the fact that the name 'Arthur Nikisch' is impressed on the front cover. Nikisch (1855-1922) never visited Australia but was a frequent visitor to London, and Goossens had played under his baton. ${ }^{56}$ On the occasion of conducting Nikisch's former orchestra, the Berlin Philharmonic, Goossens was presented with a souvenir: the baton that Nikisch had used at his last concert. ${ }^{57}$ Goossens also notes of his experience with the Berliners that:

a baffling problem was to make the whole orchestra attack a fortissimo unison passage on the beat, and not slightly after it. This was a trick that Nikisch alone was responsible for, he having taught the men to delay the attack by an appreciable fraction of a second after his baton had actually indicated it..$^{58}$

There are significant points of connection between Goossens and Nikisch, and it is not impossible that the presentation of Nikisch's last baton was also accompanied by one of the Maestro's scores. The Liszt score is marked in pencil in several colours, showing evidence of two hands, perhaps more. There are detailed markings throughout, including Retuschen and

\footnotetext{
${ }^{54}$ Goossens, Overture and Beginners, 129.

${ }^{55}$ Westlake, Eugene Goossens, 364.

${ }^{56}$ Goossens, Overture and Beginners, 195. To date, Nikisch's score library has not been located.

${ }^{57}$ Goossens, Overture and Beginners, 196.

${ }^{58}$ Goossens, Overture and Beginners, 197.
} 
added phrasing and dynamic indications in an old-fashioned hand. Apart from a possible connection to Goossens, the binding clearly indicates that the score belonged to Nikisch and likely contains his markings. The fact that Goossens conducted the Australian premiere of the work adds weight to the possibility that the score belonged to Goossens. It must be noted, however, that the SANML inventory lists a copy of the Faust Symphony from the same publisher, and that this score may have been a part of that collection.

The association between Pierné and Goossens has already been discussed, raising the possibility that a score of Pierné's Poëme symphonique, op. 37 (ca 1902) [4982611] may have been part of Goossens' library. This is a beautifully copied and bound manuscript-a connoisseur's piece-which bears a number of annotations, including the composer's Paris address, along with a stamp 'Joh. Wijsman, Amsterdam,' probably that of Dutch pianist Johan Wijsman (1872-1913)..$^{59}$ There is also a stamp of the publisher 'J. Hamelle à Paris' and the number J.4772 $\mathrm{H}$, which is also the plate number of the engraved score of the work. The final page appears to be signed by the composer. This may be one of a series of hand-copied scores, created for distribution prior to the work becoming available in printed form. Again, a Goossens provenance remains circumstantial.

A score of Symphony No. 6 (1923) by Jean Sibelius (1865-1957) [4980121] contains no inscriptions or owner's marks, aside from the signature 'S. Sydney Turner.' This is most likely Saxon A. Sydney-Turner (1880-1962), a shadowy, eccentric figure with an interest in music who was associated with the Bloomsbury Group. ${ }^{60}$ It is likely that Goossens and Sydney-Turner moved in the same circles in London. The score is a specialised item, Goossens himself having noted around 1950 that 'today, symphonies 1, 2 and 5 alone seem to evoke the old enthusiasm.' ${ }^{61}$ Goossens befriended the composer during the latter's conducting visits to London and championed his music, performing the Seventh Symphony in Sydney with the SSO in April $1950 .^{62}$

Charles Villiers Stanford (1852-1924) was Goossens' composition teacher and an important formative influence. ${ }^{63}$ One of Goossens' earliest conducting assignments for Beecham was to take over performances of Stanford's opera The Critic (1915). ${ }^{64}$ According to his pupil, Stanford combined elements of Saint-Saëns and Glazunov, being:

their English counterpart, a fact which accounts for his constant references to both composers in his composition classes, and his obvious and intense delight in performing their music, for Stanford combined both the orderliness of Saint-Saëns and the romanticism of Glazunov. ${ }^{65}$

This orchestral version of Stanford's Songs of the Fleet: A Cycle of Five Songs, op. 117 (1910) [4999888] is in manuscript, beautifully copied by an unknown hand. It may have been owned by Stanford's erstwhile pupil, while a stamp, 'Palings \& Co., Sydney,' suggests that the score was purchased in Australia.

\footnotetext{
${ }^{59}$ Wouter Kalkman, 'First Berlin period (1904-1914)', Sergei Bortkiewicz: His Life and Music https: / / sergeibortkiewicz.com/ first-berlin-period-1904-1914.

${ }^{60}$ Roy Johnson, 'Saxon Sydney-Turner Biography: Intellectual, Aesthete, Enigma, and Civil Servant,' Mantex Information Design, http: / / mantex.co.uk/saxon-sydney-turner-biography.

${ }^{61}$ Goossens, Overture and Beginners, 75.

${ }^{62}$ Westlake, Eugene Goossens, 364.

${ }^{63}$ Goossens, Overture and Beginners, 80-81.

${ }^{64}$ Ford, 'Sir Eugene Goossens,' 5.

${ }^{65}$ Ford, 'Sir Eugene Goossens,' 5.
} 
None of these scores bear conclusive Goossens provenance, although each is unique, rare, and of considerable intrinsic value, exhibiting clear synergies with the life and work of the conductor. One might question how these scores could have made their way to Australia if not brought by Goossens.

\section{The Remaining Material in the EGC}

The material in the EGC contains many scores, the provenance of which needs to be tested. Some suggest a possible connection to Goossens; for example, Henry Horn's Rudiments for the Single and Double Movement Harp (1810-1816) [4980777] reminds us that the Goossens family boasted a proliferation of harpists - two of Eugene III's sisters and one of his daughters-though this volume is clearly signed 'Fred Haines, 1900.' This returns us to the SANML collection, and the inventory that mentions thirty boxes of scores, of which around half (fifty-two works) had been sampled. It seems likely on account of the age of the material, the inclusion of Lyster's scores, and the frequent appearance of Haines' name that the remaining material in the EGC originated largely from the SANML and was among the unsampled material in the remaining fifteen boxes.

Figure 2. Eugene Goossens, from The Canon, July 1952 (private collection, Sydney)

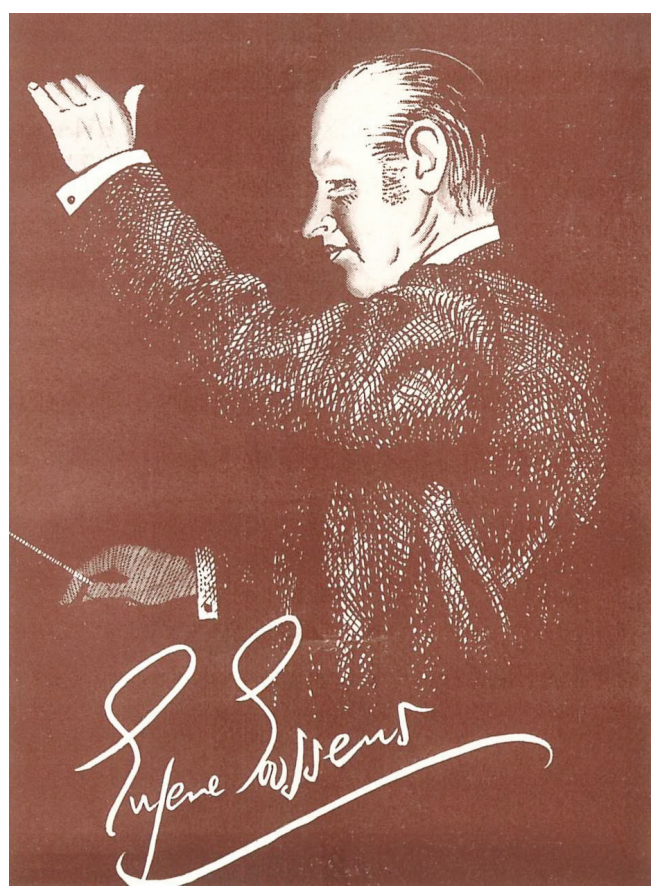

\section{Goossens and His Scores}

Further confirmation that Goossens moved substantial parts of his music library to London in 1956 can be found in his will, ${ }^{66}$ where he states that 'all my printed library shall go to my sister, Sidonie Goossens-Millar. ${ }^{\prime 67}$ Rosen describes this in more detail, noting that 'he had appointed

\footnotetext{
${ }^{66}$ Goossens' will was hastily made in Geneva on 2 June 1962, only a few days before his death, and witnessed by his landlady. Photocopy in possession of the author (private collection, Sydney).

${ }^{67}$ Sidonie Goossens-Millar (1899-2004) was a well-known harpist of the BBC Symphony Orchestra.
} 
Sidonie his executrix and left her his printed music that included the historic opera scores from which he, his father and his grandfather had all conducted. ${ }^{68}$ Pamela Main, Goossens' companion in his final years, was left the residue of his estate, which consisted largely of manuscripts of his compositions along with extensive correspondence covering the span of his life. In 1993, Main established the 'Sir Eugene Goossens Archive,' ordering and cataloguing the material she was bequeathed, and eventually donating the entire collection to the British Library. Sidonie died in 2004, leaving artworks and her harps to specific beneficiaries, but of Goossens' score library there was no mention. ${ }^{69}$ Sidonie would certainly have been aware of the significance and importance of her brother's bequest to her; perhaps she donated the scores to an institution following the conductor's death and prior to her own. I have made enquiries at a number of likely institutions, without any result. The British Library has confirmed that it holds the collection donated by Main, consisting of musical manuscripts and correspondence; however, it holds no printed music or scores apart from Goossens' own compositions. ${ }^{70}$ It is hoped that the score library bequeathed to Sidonie is located in the future, to allow this field of Goossens research to broaden.

\section{Tracing Eugene Goossens in the EGC}

Here follows a summary of the circumstances of the donation of the EGC to the NLA, its components, and a proposal for clarifying the subsections of the collection. The EGC was donated by Symphony Services to the NLA, at which time it was described as a collection of scores formerly owned by Eugene Goossens, and duly catalogued as such. A closer study of the contents has revealed that only part of the EGC contains scores owned by Goossens: a subsection that I have called the G(oosens) C(ollection) and outlined in Tables 1 and 2. There are at least six subsections within the EGC: the GC of scores, EG1-69 (Table 1); other Goossens material of clear provenance (Table 2); other material of possible Goossens provenance (Table 3); scores from SANML owned by Lyster; scores from SANML owned by Haynes; and scores from the former Federal Music Library, some of which were also part of the SANML collection. In addition, the NLA holds other important Goossens items elsewhere in its collections.

Some material is of uncertain origin and, in the case of Goossens, it cannot be discounted that certain items - as demonstrated by the four scores in Table 3-may well have belonged to the conductor, based on circumstantial evidence. Nevertheless, the core of the GC can be established with some certainty (Tables 1 and 2). Due to the persistence of grey areas, as well as general conventions of library practice, it would be impractical to undertake a physical separation of the EGC's subsections at this point. ${ }^{71}$ Perhaps a different name could be applied to the EGC to reflect the other material that it contains. Including more information on the NLA website about the collection would be a valuable resource for those wishing to study it further. The provenance and background of the various subsections could be then described in detail, and the grey areas that surround some of the material could be noted.

\footnotetext{
${ }^{68}$ Rosen, The Goossens, 387.

${ }^{69}$ Her will was made on 12 March 1998, and is available through the UK Probate Office, probate no. 1816395, https: / / probatesearch.service.gov.uk.

70 The British Library holds no conducting or marked scores of Goossens, as confirmed in email correspondence with the author.

${ }^{71}$ Usual archival practice is not to impose order upon a collection at the time of acquisition.
} 
Further research is likely to clarify some of the current uncertainties around the collection, and the material itself may yield further clues about the provenance of doubtful items. The SANML collection should be identified as a subsection, and the further subsections within it should be articulated, including the scores of Lyster and Haines. The fascinating array of material that bears Haines's name suggests an enquiring musician of wide tastes that extend to the antiquarian, whose life and place in the musical life of Australia would certainly bear further study. The Federal Music Library scores may originate partly from the SANML collection, as well as contain miscellaneous material that was deaccessioned from the Symphony Services Library.

Descriptions in the NLA catalogue indicate that the non-Goossens material consists of a number of rare and valuable items, which are of considerable historical, cultural, and musical interest, at least as significant as the Goossens material. Articulating the subsections of that area of the collection would render it visible and accessible for the further research that the material certainly warrants.

The Goossens material in the EGC has considerable potential as a tool for research, and the collection's acquisition acts as a reminder of a particularly rich period in Australia's musical history and the development of the $\mathrm{ABC}$ state orchestras. It demonstrates in documentary form the wide-ranging musical tastes, interests, and experience that Goossens brought to Australia, and informs the musical legacy that he left behind. A greater sense of clarity around the components of the EGC will enable further research in a number of areas and may well uncover some neglected chapters of Australian musical history.

Figure 3. 'Gene' Goossens, from The Canon, July 1952 (private collection, Sydney)

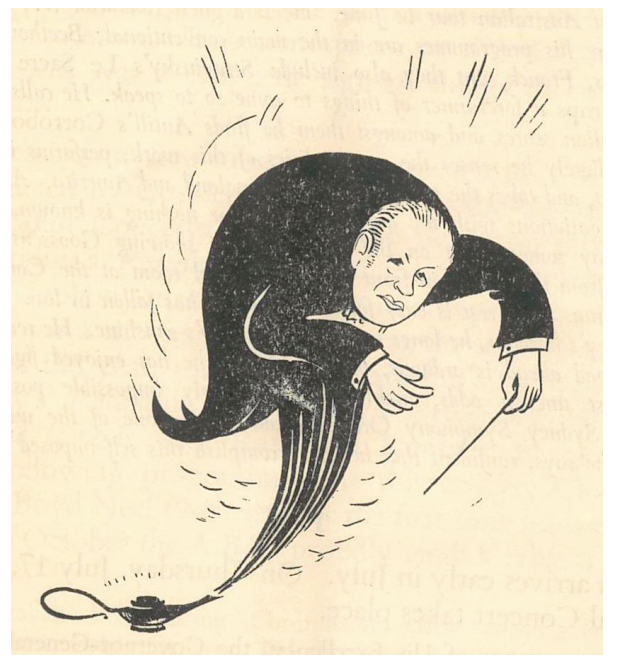

\footnotetext{
About the Author

Stephen Mould is Senior Lecturer in Operatic Studies, Repetiteurship and Conducting at the Sydney Conservatorium of Music. He has worked extensively as a conductor in Europe, Australia, New Zealand and Asia, and made his American debut with the Baltimore Opera in 2008. He is the author of Curating Opera: Reinventing the Past Through Museums of Opera and Art (Routledge, 2021), and co-author of The Marks of a Maestro: Annotating Mozart's Jupiter Symphony (CUP, 2021).
} 